УДК 614.253: 378.015.31:17.022.1

https://doi.org/10.52058/2786-4952-2022-2(7)-59-67

Semenova Liudmyla Serhiivna Candidate of Medical Sciences, Associate Professor, Associate Professor of the Department of Social Medicine, Public Health and Healthcare Management, Dnipro State Medical University, V. Vernadsky St., 9, Dnipro, 49044, tel.: (097) 501-12-62, https://orcid.org/0000-0002-7421-9174

Klymenko Iryna Mykolaivna Teacher of Language Training Department, Dnipro State Medical University, V. Vernadsky St., 9, Dnipro, 49044, Ukraine, tel.: (063) 394-67-50

Romanyuta Inna Anatoliyivna Candidate of Medical Sciences, Associate Professor of Therapeutic Dentistry, Dnipro State Medical University, V. Vernadsky St., 9, Dnipro, 49044, tel.: (067) 562-70-71

Samoilenko Iryna Ihrivna Candidate of Medical Sciences, Associate Professor of Dentistry Dnipro Medical Institute of Traditional and Alternative Medicine, Academician G. Dziak St., 3, Dnipro, 49005, tel.: (067) 147-01-13

\title{
MORAL EDUCATION OF MEDICAL STUDENTS AS AN IMPORTANT COMPONENT OF TRAINING FUTURE DOCTORS
}

Abstract. An analysis of recent research and publications shows that reforming the National Health Service requires a change in the education system. An important area of training of modern doctors is not only the training of highly qualified and professionally competent medical workers, but also specialists with high moral qualities, able to build confidenctial relationship with patients. Therefore, the aim of the study is to develop measures on improving moral education of medical students.

To develop the content of moral education of medical students using the historical method of research, the life and work of prominent professionals in the world of medical science were analyzed. Among them there were individuals whose lives and activities can be an example of high ethical standards of humanism (such as Theodore Haas, John Howard, Albert Schweizer).

The life and activity of doctors and scientists who worked in our city were also analyzed, namely:

- Nikolai Pirogov and his training of the Sisters of Charity,

- Ivan Leshko-Popel and his selfless help to the poor,

- the first rector of the Ekaterinoslav Medical Academy, Professor Vladimir Porfiriyevich Karpov and his works on ethical issues, 
Журнал«Герспективитаінноваціїнаукиљ

(Серія«Гедагогіка», Серія«ГТихологія», Серія«Медицинв»

№2(7) 2022

- Professor Ivan Logvinenko and his principles of educating student youth and forming a culture of relationships among colleagues,

- Professor Yakov Grigoriyevich Kovrov and his contribution to the patriotic education of youth

In addition, the importance of studying the works of Anton Chekhov (born in Ekaterinoslav province) and his literary type of humanist doctor was shown.

The importance of studying the humanities and language training is emphasized for the formation of the future doctor's personality.

Proposed measures to improve the moral education of medical students: to create a scientific-methodical and educational center for moral education of medical students on the basis of departments of humanities, to create an electronic bank of methodical and special literature on moral education of medical students, to ensure the holding of regular seminars for teachers of moral education of medical students, to include issues of moral education of students in advanced training courses for teachers.

Keywords: humanism, moral education, medical students

Семенова Людмила Сергіївна кандидат медичних наук, Доцент кафедри соціальної медицини, громадського здоров'я та управління охорони здоров'я, Дніпровський державний медичний університет, вул. В.Вернадського, 9, м. Дніпро, 49044, тел.: (097) 501-12-62, https://orcid.org/0000-0002-7421-9174

Клименко Ірина Миколаївна викладач кафедри мовної підготовки, Дніпровський державний медичний університет, вул. В.Вернадського, 9, м. Дніпро, 49044

Романюта Інна Анатоліївна кандидат медичних наук, Доцент кафедри терапевтичної стоматології, Дніпровський державний медичний університет, вул. В.Вернадського, 9, м. Дніпро, 49044, тел.: (067) 562-70-71

Самойленко Ірина Ігорівна кандидат медичних наук, Доцент кафедри стоматології, Дніпровський медичний інститут традиційної і нетрадиційної медицини, вул. Акадміка Г.Дзяка, 3, м. Дніпро, 49005, тел.: (067) 147-01-13

\section{МОРАЛЬНЕ ВИХОВАННЯ СТУДЕНТІВ-МЕДИКІВ ЯК ВАЖЛИВИЙ КОМПОНЕНТ НАВЧАННЯ МАЙБУТНІХ ЛІКАРІВ.}

Анотація. Аналіз останніх досліджень, публікацій свідчить,що реформування Національної охорони здоров'я потребує зміни системи освіти. Важливим напрямком підготовки сучасних лікарів $\epsilon$ не тільки навчання висококваліфікованих та професійно компетентних медичних працівників, але й спеціалістів 3 високими моральними якостями, спроможними будувати довірчі стосунки 3 пацієнтами. Тому метою дослідження є розробка заходів щодо 
покращення морального виховання студентів-медиків.

Для розробки змісту морального виховання студентів-медиків 3 використанням історичного методу дослідження було проаналізовано життя та діяльність видатних професіоналів у світі медичної науки. Серед них були виділені особистості, життя та діяльність яких можуть бути прикладом високих етичних норм гуманізму (Теодор Гааз, Джон Говард, Альберт Швейцер).

Також проаналізовано життя та діяльність лікарів та вчених, які працювали у нашому місті, а саме:

- Микола Пирогов та його підготовка сестер милосердя,

- Іван Лешко-Попель та його безкорислива допомога бідним людям,

- перший ректор Катеринославської медичної академії професор Володимир Порфірійович Карпов та його праці, присвячені етичним питанням,

- професор Іван Олександрович Логвіненко та його принципи виховання студентської молоді та формування культури взаємовідносин серед колег,

- професор Яків Григорович Ковров та його внесок в патріотичне виховання молоді

Крім того було показано значення вивчення творів Антона Чехова (народився в Катеринославській губернії) та його літературного типа лікарягуманіста.

Для формування особистості майбутнього лікаря підкреслено важливе значення вивчення гуманітарних дисциплін, мовної підготовки.

Запропоновані заходи, щодо покращення морального виховання студентівмедиків, а саме: створити науково-методичний та освітньо-виховний центр 3 морального виховання студентів-медиків на базі кафедр гуманітарних дисциплін, створити електронний банк методичної та спеціальної літератури 3 морального виховання студентів-медиків, забезпечити проведення регулярних семінарів для викладачів 3 морального виховання студентів-медиків, включати питання морального виховання студентів до курсів підвищення кваліфікації викладачів.

Ключові слова: гуманізм, моральне виховання, студенти-медики.

Problem formulation: The quality and effectiveness of medical care is determined not only by the high qualification and professional competence of medical workers of various specialties, but also by their personal characteristics, attitudes, motivations, psycho-emotional and physical condition.

The education system in Ukraine conveys principles of humanism and cultural diversity. Radical changes being introduced in the national higher medical education have been triggered by the process of the country's integration into European Community, this implies greater mobility for students, more effective international communication, better access to information and deeper mutual understanding. In order to train professional doctors with high moral qualities it is important to understand the best achievements of the world in this field.

Analysis of recent research and publications: The treatment of many diseases is impossible without taking into account the socio-psychological characteristics of 
the individual, relationships with the environment, which requires the doctor to be able to build trusting relationships with the patient. The Edinburgh Declaration of the World Federation of Medical Education stated that each patient should be able to meet a person trained as an attentive listener, a careful observer, an effective clinician, and also a person who is highly susceptible in the field of communication in the person of a doctor [ 1 ] .

Analysis of general knowledge of students about medical scientists and value orientation of future doctors showed that most respondents of all courses of study answered that physician must be a skilled practitioner. But at the same time, students of general medicine more often than students of dentistry answered that a modern doctor should have such humane qualities as empathy, mercy, patience, tolerance and selflessness. Some students (60\%) also were insufficiently informed about our native doctors. [2].

This indicates that it is advisable to further strengthen educational work among students to form personality of a modern doctor of full value.

The purpose of the article is to develop measures on improving the moral education of medical students, as well as to study the activities of prominent domestic and foreign philanthropists.

Presentation of the main material: Analysis of the activities of prominent domestic and foreign philanthropists showed that:

Our eminent scientist Danylo Samoilovych noted: "All those who are prepared to become doctors should be merciful, compassionate, helpful ... and love your neighbor as yourself..., not to be avaricious or covetous in money matters; avarice and greed - two vices that disgrace doctor. ... To become a doctor, you have to be a perfect man".

An example of high ethical standards of humanism was outstanding physician and philanthropist Theodore Haas (1780-1853). All his funds he directed to help the poor and prisoners. On the pedestal of his monument the following words were engraved: "Harry up for good Deeds".

A British social activist, philanthropist, reformer of prison affairs John Howard (1726-1790), who participated in the fight against epidemics in southern Ukraine and perished here is distinguished by a high humanism.

Albert Schweitzer (1875-1965) is a German and French philosopher, doctor of philosophy, theology and medicine, author of fundamental works on theology. In Africa (Gabon) he built hospital and for a long time delivered medical care to local residents. He was awarded the Nobel Prize of Peace for the great humanistic activities in safeguarding of peace, the Prize was lashed out on the treatment of leprosy in Africa [3].

Some students also were insufficiently informed about our native doctors. That is why it is important to use examples of activities of doctors who lived and worked in Ukraine and in our city for moral education:

Nikolai Ivanovich Pirogov, a famous scientist, surgeon known worldwide who lived in Ukraine and treated the wounded in Yekaterinoslav (now Dnipro) paid great 
attention to meticulous care for the patients and wounded helping their quick recovery. He was the first who used help from the civilian population for this purpose, namely sisters of mercy. He wrote: "The duties of sisters of mercy at dressing stations were diverse and important for their consequences for the patients both in physical and moral aspect"'[4].

Our prominent doctor and humanist Ivan Leshko-Popel who lived in Yekaterinoslav in the late XIX and early XX century is an example of selfless service to the people. He was called as "friend of the poor", "people's doctor", "prominent doctor-man". His life and humanitarian desire can be used as an example for the moral education of the doctors-to-be based on the best traditions from the past years.

Ivan Leshko-Popel differed from many of his coworkers because he was filled with special sensitivity and responsiveness. He was a man of great soul, with a deep understanding of the medical duty. Around the clock residents of Yekaterinoslav were knocking on his door, asking for help and he was always ready, "to help the patient and to walk to the opposite end of the city on foot, to Kaidak or Amur (suburbs of the city) where people were waiting for him as a hope, as a healer"[5].

The works of the famous life scientist, the first Rector of Yekaterinoslav medical academy Professor Vladimir Porfiriyevich Karpov are devoted to the ethical issues of medicine. In his work "Hippocrates and Hippocrates's collection" Professor V.P.Karpov outlines that Hippocrates suggests following the principle of individualization in treatment with a strict observance of ethical norms. It should be noted that Professor V.P.Karpov was both a talented scientist and a brilliant pedagogue. He paid great attention to studies and pedagogical work. He believed that lectures were the fundamentals of teaching and education process. His lectures, as remembered by his listeners, were brilliant in substance and profound in form. Therewith he always considered the level of preparedness of the audience. Young students loved him. Vladimir Porfiriyevich raised the pleiad of disciples, such eminent scientists as M.L.Gerbilsky, N.Kh.Flerov, etc. [6].

Professor Ivan Aleksandrovich Logvinenko who was the head of the Department of Social Hygiene and Health Care Management of Dniepropetrovsk Medical Academy considered that upbringing of students youth should be directed at formation of not only high professional but moral traits. He paid great attention to culture of mutual relations of colleges. He said "The atmosphere in the team should teach the beauty of human relationships, the culture of thoughts and actions. Professor I.A. Logvinenko was always the first to come to work, beginning his working day by cleaning his office. Neatness, order and discipline should be in everything, considered Ivan Aleksandrovich. He was demanding not only of teachers and students, but above all of himself. He was characterized by dedication in work and this is what he expected from subordinates. Despite the exactingness of his work, he was a sensitive, attentive person, was like a father to young colleagues and students, he knew their social and everyday problems, often meeting with students in hostels [7].

Professor Yakov Grigoriyevich Kovrov was the head of the Department of Hygiene of Children and Adolescents of Dnipropetrovsk Medical Institute. He paid 
great attention not only to pedagogical and scientific, but also educational work among students. Yakov Grigoriyevich paid particular attention to the patriotic education of youth [8].

Patriotic education of students can be carried out on the examples of teachers and students of our academy who fought the enemy during the Second World War. We will never forget the feat of such our students as Igor Klyuev, Galina Romanova and Lyuba Tarasova who gave their lives for the liberation of Ukraine. Mikhail Yefimovich Demko and professor Yevgenia Georgiyevna Popkova who worked in the Dnepropetrovsk underground brought the hour of victory over the enemy closer [9].

The activity of many of the graduates and teachers of our academy is a vivid example of devotion to the cause.

Literary heroes can be used for moral education as well, an example - literary heroes of Anton Pavlovich Chekhov who was not only a well-known writer worldwide, he was a doctor.

Anton Chekhov is our domestic writer. He was born in Taganrog, a port on the Sea of Azov in the Yekaterinoslav Governorate.

Anton Chekhov was well-informed about the human soul and could describe the best personality traits, and a lot of literary types of cultured doctor, a doctor-humanist appeared in the world literature.

Anton Chekhov described a portrait of a kind doctor who did not leave a sick man at hard times, he saved his life (the story "Typhus").

Thanks to a delicate, responsive doctor in Chekhov's story "Attack" his hero gained mental balance and rest.

Anton Chekhov described humane feelings of a doctor who treated a hopelessly ill boy, the doctor considered that boy to be his own son (the story "Doctor").

Despite of a big sorrow that came into the family of the doctor Kirilov - death of his son, but the same evening he fulfilled his duty of a doctor - went to save the life of another person (the story "Enemies").

Talented and respected doctor Dymov always treated his patients selflessly. $\mathrm{He}$ saved the life of a seriously ill boy. The doctor got infected with severe disease which led to his death (the story "Jumper").

The portrait of an honest, selfless doctor who had not been on leave for decades was described by Chekhov (the story "Princess").

Personage of a kind, merry doctor was described by Chekhov as medical profession requires striking a chord with any person (the story "Fugitive").

A well-known doctor, scientist, professor knew that because of a serious illness he would close his days soon. But he tried to be active till the end of his life, to benefit people, to work heartily and to be useful for the society (the story "A Boring Story").

Doctor Astrov tells that he has been working hard from the morning till the evening without day-offs and even at night he could be called in (the story "Uncle Vania"). 
An honest, hard-working, humane doctor was described by Chekhov in the story "Ionych" [10].

Language training is one of the most important conditions for training a specialist in any field. The level of this training largely determines the quality of education and the effectiveness of further professional activity. Moreover, language training contributes to the moral education of medical students.

The questions of humanitarian content are debated with the students of the $1 \mathrm{st}$ and 2nd course at the language training department while studying life and professional activity of representatives of world science and culture. At each lesson of the Latin language teachers of the department pay special attention to the section of the textbook entitled "Do you know that"... which deals with some historical and cultural events connected with medical science and students can study the best human qualities and values [11].

This learning contributes not only to upbringing of humanity and compassion, but also forms a certain level of culture, intelligence and education. A significant part of the humanitarian material included in the Latin language course is devoted to Latin sayings and proverbs with the aim to provide information about ancient social order and philosophy consists of words and expressions of ancient origin: "apple of discord", "Achilles heel", "Medusa's head". Nevertheless, not each student can correctly understand the meaning of the phrase because they are not familiar with the samples and characters of ancient mythology, episodes of history. That is why some words especially require qualified commentary of the teachers.

Language learning is oriented at studying English to be able to use it practically in the field of work. Moreover, topic areas, situations and text types also form a certain level of culture in accordance to professional needs and contexts. It contributes to the strengthening a culture of behavior based on the principles of humanity. It is important because students of medicine should be able to deal with patients $[12,13]$.

For practical possessing of a foreign language, moral education of students, in classrooms in the English language students are proposed original medical articles or abstracts from original English and American novels like A.J.Cronin "The Citadel", A.Hailey "The Final Diagnosis", W.S.Maugham "The Summing Up", A.Walker "Medicine" etc.[14].

Thus, humanitarian disciplines play an important role in the formation of professional competencies of future doctors, contribute to the accumulation of special medical knowledge and develops the ability to put those into practice, and also promote moral education. By studying the life and work of outstanding professionals in the world of medical science students will acquire not only special knowledge but form themselves as individuals concentrating on the best human qualities and values, that is why humanitarian subjects provide not only medical information, but has a great educational value.

The humanities enrich general cultural and medical outlook of the future doctor, help to master his profession, to keep the devotion to patient and responsibility to the 
community, to unite different branches of science. At the same time, the humanities help to acquire and develop knowledge that are components of the art of medicine: humanism, altruism, diligence, high moral-ethical quality. Additionally, the physician must have knowledge that can be called "a special feeling.

\section{Conclusions:}

With the purpose to improve moral education of medical students we offer:

1. to create scientific methodological and educational center for moral education of medical students on the bases of departments of humanitarian disciplines;

2. to create an electronic bank of methodical and special literature on moral education of medical students;

3. to provide regular seminars for teachers on moral education of medical students;

4. to include issues of moral education in the courses of professional development on pedagogic.

\section{References:}

1. Spirina, I.D., Vitenko, I.S., \& Naprienko, A.K. (2014). Medychba psyhokogaya [Medical psychology]. Dnipro::Promin [in Ukrainian].

2. Semenova, L.S, \& Klimenko,I.M. (2019). Vazhlyvist vyvchemnia istorii medyrsyny ta movnoi pidgotovky dlia rozvytku profesiinykh kompetentnostei medychnykh studentiv [The importance of studying history of medicine and language training for the development of professional competencies of medical students]. Medychni perspectyvy-Medical Perspectives, 1, 31-34 [in Ukrainian].

3. Stupak, F.Y. (2016). Istoriia medytsyny [History of medicine]. Kyiv: Kniga-plus [in Ukrainian].

4. Semenova, L.S., \& Koriahin, Yu.A (2015).Znachennia naukovykh idei M.I.Pyrogova dlia suchasnoi organizatsii okhorony zdorovia [The value of scientific ideas of M.I. Pirogov for the modern organization of health care]. Medychni perspektyvy-Medical Perspectives, 1, 143-145 [in Ukrainian].

5. Semenova, L.S. (2017). Vaznlyvist vyvchenia diialnosti I.V.Leshko-Popelia dlia moralnogo vykhovannia medychnykh studentiv [Impotance of studying I.V. Leshko-Popel activities for moral education of medical students]. Medychni perspectyvy-Medical Perspectives, 1, 141-146 [in Ukrainian].

6. Semenova, L.S. (2013). Pamiati propessora Volodymyra Porfiriyvicha Karpova [In memory of Professor Volodymyr Porfiriovych Karpov]. Medychni perspektyvy-Medical Perspectives, , 3, 157-159 [in Ukrainian].

7. Semenova, L.S. (2015). Zhadaimo vchytelia ta kolegu Ivana Oleksanrovycha Logvunenka [Let us remember the teacher and colleague Ivan Aleksandrovic Logvinenko]. Medychni perspektyvy-Medical Perspectives, 1, 146-147 [in Ukrainian].

8. Lekhan, V.M., \& Semenova, L.S. (2009). Professor Kovrov Yakiv Hryhorovych [Professor Kovrov Yakiv Hryhorovych]. Medychni perspektyvy-Medical Perspectives, 3, 117-118 [in Ukrainian].

9. Semenova, L.S .(2005). Poklonymos Velykym tym rokam [Let us worship the Great Years]. Medychni perspektyvy-Medical Perspectives , 2, 145-150 [in Ukrainian].

10. Semenova, L.S., \& Klimenko, I.M. (2018). Anton Chekhov ta yogo literaturni tvory yak dzherelo vyvchennia gumanizma v medytsyni [Anton Chekhov and his literary works as a source of studying humanism in medicine]. Medychni perspectyvy, -Medical Perspectives 1, 139-144 [in Ukrainian].

11. Smolska, L.Yu. (2012). Latynska mova ta osnovy medychnoi terminologii [The Latin Language and Medical Terminology Basics]. Kyiv: Medytsyna [in Ukrainian].

12. Bakaiva, G.E. (2004). Angliiska dlia spetsialnogo pryznachennia v Ukraini [English for Specific Purpose (ESP) in Ukraine]. Kiev: Lenvit [in Ukrainian].

13. Avrahova, L.Ya. (2012). Angliiska dlia meduchnykh studentiv [English for Medical Students]. Kiev: Medytsyna [in Ukrainian]. 
14. Reyholds, R., Stone, G., Nixon, L., \& Wear, D. (1995). Pro likuvania [On doctoring]. Niu York: Simon and Schuster [in USA].

\section{Лimepamypa:}

1. Спіріна І. Д. Медична психологія: підручник / І.Д. Спіріна, І.С. Вітенко, А.К. Напрієнко. Дніпро: Промінь, 2014. - 456 с.

2. Semyonova L.S. The importance of studying history of medicine and language training for the development of professional competencies of medical students /L.S. Semyonova, I.M. Klimenko // Медичні перспективи.- 2019-. №1.-С. 31-34.

3. Ступак Ф. Я. Історія медицини: підручник / Ф. Я. Ступак. - К: Книга-плюс, 2016. - 128 с.

4. Семенова Л. С. Значення наукових ідей М.І. Пирогова для сучасної організації охорони здоров’я/ Л.С. Семенова, Ю.А. Корягін// Медичні перспективи. - 2015. - № 1. - С. 143-145.

5.Semyonova L. S. Impotance of studying I.V. Leshko-Popel activities for moral education of medical students/ L. S. Semyonova// Медичні перспективи. - 2017.- № 1.- С. 141-146

6. Семенова Л. С. Пам'яті професора Володимира Порфирійовича Карпова/ Л.С. Семенова// Медичні перспективи. - 2013. - № 3. - С. 157-159.

7.Семенова Л. С. Згадаймо вчителя та колегу Івана Олександровича Логвіненка/ Л.С. Семенова //Медичні перспективи. - 2015. - № 1. - С. 146-147.

8. Лехан В. М., Професор Ковров Яків Григорович/ В.М. Лехан, Л.С. Семенов// Медичні перспективи. - 2009. -№ 3. - С. 117-118.

9. Семенова Л. С. Поклонимось Великим тим рокам/ Л.С. Семенова// Медичні перспективи. - 2005. - № 2. - С. 145-150.

10. Semyonova L. S. Anton Chekchov and his literary works as a source of studying humanism in medicine//L.S. Semyonova, I.M. Klimenko// Медичні перспективи. - 2018.- № 1. C. 139-144.

11.СмольськаЛ.Ю.Латинська мова та основи медичної термінології/Л.Ю.Смольська. К.:Медицина,,2010- 440 с.

12. Аврахова Л. Я. Англійська мова для студентів-медиків.: підручник/ Л. Я. Аврахова. - К.: Медицина, 2012. - 440с.

13. Бакаіва Г. Е. Англійська для спеціального призначення в Україні: навч. посіб./ Г.Е. Бакаіва. - К.: Ленвіт, 2004. - 118 с.

14. On doctoring/ R. Reyholds, G. Stone, L. Nixon, D. Wear. - New York: Simon and Schuster. 1995. - 118 c. 